\title{
Protecting Surface Water from Sediment-Associated Pesticides in Furrow-Irrigated Crops
}

RACHAEL LONG, University of California Cooperative Extension Farm Advisor, Yolo County; ALLAN FULTON, University of California Cooperative Extension Farm Advisor, Tehama County; BLAINE HANSON, Extension Specialist, Land, Air, and Water Resources, University of California, Davis

\section{Impact of Pesticides on Receiving Waters}

Pesticides occur in some California waterways as dissolved materials or attached to suspended sediments that settle out and accumulate in mud deposits. Certain pesticides may persist for only a few days, but others, such as DDT, may last for decades. Although pesticide concentrations in waterways are usually within drinking water standards, they are still high enough to cause toxicity to aquatic life. The pesticides found primarily include currently registered materials, although prohibited products such as DDT and its byproducts (DDE, DDD) are also still being found (Weston et al. 2004).

Pesticides can enter surface waterways directly from specific ("point”) sources such as drift or spills. However, more general and widespread ("nonpoint") sources from both agricultural and urban uses are of increasing concern. Certain pesticides, including many organophosphates such as diazinon and chlorpyrifos, are readily picked up from the soil and dissolve in irrigation or storm water runoff as it moves across treated areas. Other pesticides, such as pyrethroids, are relatively insoluble in water. These pesticides move offsite attached to soil particles in water runoff, where they eventually settle out and contaminate downstream areas. Fine soil particulates are of particular concern because the pesticide concentration of soil-sorbed pesticides can be ten times higher than that in coarser particles such as sand, and the particulates tend to stay suspended in water the longest, potentially contaminating water at a greater distance from their source.

To protect surface waters from pollutants, the California State Water Resources Control Board (SWRCB) has implemented requirements that allow farmers to discharge irrigation and storm water runoff from farms into state waters as long as the runoff water does not impair the beneficial uses of the receiving water. For pesticides and many other pollutants, these water quality standards seek to ensure that discharge water from agricultural sources does not cause toxicity to aquatic life, including organisms that live in the water, such as some crustaceans, algae, and fish, as well as invertebrates that dwell in the bottom mud deposits. 
The SWRCB currently grants waivers to allow growers to discharge water into state waterways as long as growers make efforts to meet state water quality standards. To help comply with water quality regulations, growers should follow best management practices to minimize pesticide use in crop production. This includes the use of resistant plant varieties, certified seed, and integrated pest management (IPM) practices. The safe use, storage, and handling of pesticides, as well as reading and following the pesticide label carefully as state law requires, will also help protect water quality. Information on pesticide use for crop production, including IPM and best management practices can be found in the University of California (UC) IPM guidelines and in Long et al. 2005.

This publication provides information on management practices to help reduce the impact of pesticides on surface water quality when runoff occurs from furrow-irrigated crops. The discussion includes the chemistry and toxicology of pesticides to better understand their potential impact to water quality, irrigation management practices that help reduce surface runoff, and strategies for keeping sediments and sedimentassociated pesticides from moving offsite in irrigation tailwater.

\section{Pesticide Properties and Water Quality}

The likelihood that a pesticide will move in irrigation or storm water runoff from an application site depends primarily on the properties of the active ingredient, including the pesticide's field dissipation half-life, soil adsorption coefficient, and aqueous solubility. Field dissipation half-life is the time required for half of a given quantity of a formulated pesticide to degrade or dissipate in the soil. The soil adsorption coefficient is the degree to which a pesticide will adhere or stick to soil particulates.
Water solubility is the amount of pesticide that can be dissolved per unit of water.

Pesticides also differ in their toxicity to aquatic life. In general, insecticides tend to have high toxicity to fish and invertebrates, while herbicides can be toxic to aquatic plants. The standard indicator species that the U.S. Environmental Protection Agency (EPA) uses for pesticides to assess water quality include the crustacean Ceriodaphnia dubia, the fathead minnow, and a green algae. Toxicity of sediment is usually assessed using the crustacean Hyalella azteca. These tests typically involve bringing the water or sediment sample to the laboratory, adding the test organism, and measuring how many organisms survive after 4 to 10 days of exposure, depending on the particular species used. The tests may also measure a sublethal endpoint, such as the ability to reproduce, or the growth rate.

The runoff potential is the likelihood that a particular pesticide will move offsite from the point of application with water. In general, when a pesticide has a high soil adsorption coefficient and low water solubility, it has a high potential to move offsite attached to soil particulates. Conversely, if a pesticide has a low soil adsorption coefficient and high aqueous solubility, it generally has a high potential for dissolving in water and moving offsite in solution runoff. The runoff potential of a given pesticide must be considered together with its half-life and aquatic toxicity to estimate its overall runoff risk. For example, a higher runoff potential combined with a higher aquatic toxicity and longer half life increases the overall risk for negative impact to water quality.

Many sediment-sorbed pesticides used in field crop production in California that would benefit from on-farm soil erosion mitigation practices based on their high risk to water quality are summarized in table 1. Pesticides with low risk to water quality should be used when possible. 
Table 1. Pesticides used in field crop production that are of high risk to water quality and would benefit from soil erosion mitigation practices to prevent off-site transport in surface water runoff.

\begin{tabular}{|c|c|}
\hline Chemical name & Trade name \\
\hline \multicolumn{2}{|c|}{ Insecticides and Miticides } \\
\hline abamectin & Agri-Mec, Zephyr \\
\hline bifenthrin & Capture \\
\hline chlorpyrifos & Lorsban, Lock-on \\
\hline cyfluthrin & Baythroid \\
\hline cypermethrin & Ammo \\
\hline diazinon & Diazinon \\
\hline dicofol & Kelthane \\
\hline endosulfon & Thionex \\
\hline esfenvalerate & Asana \\
\hline lambda-cyhalothrin & Warrior \\
\hline permethrin & Pounce \\
\hline phorate & Thimet \\
\hline propargite & Comite \\
\hline zeta-cypermethrin & Mustang \\
\hline \multicolumn{2}{|c|}{ Fungicides } \\
\hline azoxystrobin & Quadris \\
\hline chlorothalonil & Bravo, Echo \\
\hline fenbuconazole & Indar \\
\hline mancozeb & Dithane \\
\hline maneb & Maneb \\
\hline propiconazole & Tilt \\
\hline \multicolumn{2}{|c|}{ Herbicides } \\
\hline atrazine & AAtrex \\
\hline bensulide & Prefar \\
\hline diuron & Karmex \\
\hline fluazifop-p-butyl & Fusilade \\
\hline hexazinone & Velpar \\
\hline MCPA & MCPA \\
\hline norflurazon & Solicam \\
\hline oxyfluorfen & Goal \\
\hline pendimethalin & Prowl \\
\hline prometryn & Caparol \\
\hline trifluralin & Treflan \\
\hline
\end{tabular}

Source: Adapted from Long et al. 2005.
If they are not available, management practices should be implemented to minimize the pesticide's potential impact to receiving waters, as discussed in the following sections of this publication.

\section{Why Surface Runoff Occurs during Irrigation}

\section{Factors Affecting Irrigation Performance}

Furrow irrigation is an inexpensive irrigation method that uses gravity to transport water across fields that slope approximately 1 inch per 100 feet (for metric conversions, see the table at the end of this publication). The disadvantage of furrow irrigation is that performance strongly depends on the infiltration rate of the water into the soil, which in turn depends on soil type and soil structure and is therefore difficult to quantify. Due to soil variability, a single field can have various infiltration rates within it, which makes it very difficult for irrigators to accurately control water being applied to the crops. Other factors affecting irrigation performance are the roughness of the soil surface, furrow length, furrow inflow rate, and slope. Normally, a trial-and-error approach is used in the management of furrow irrigation because of the difficulty in measuring some of these factors.

\section{What happens during furrow irrigation?}

- At the start of the irrigation, water flows or advances down the furrow.

- While water is advancing, a portion of the water ponds on the soil surface in the furrow. The volume of ponded water is relatively small compared with the amount applied.

- The ponded water infiltrates the soil, and because of this infiltration, the flow rate of the water progressively decreases with distance. Thus, the inflow rate of water into furrows must be greater than the infiltration rate in order for water to reach the lower end of the furrows.

- After the water reaches the end of the furrow, surface runoff occurs, which is initially very small but increases with time ( fig. 1). 


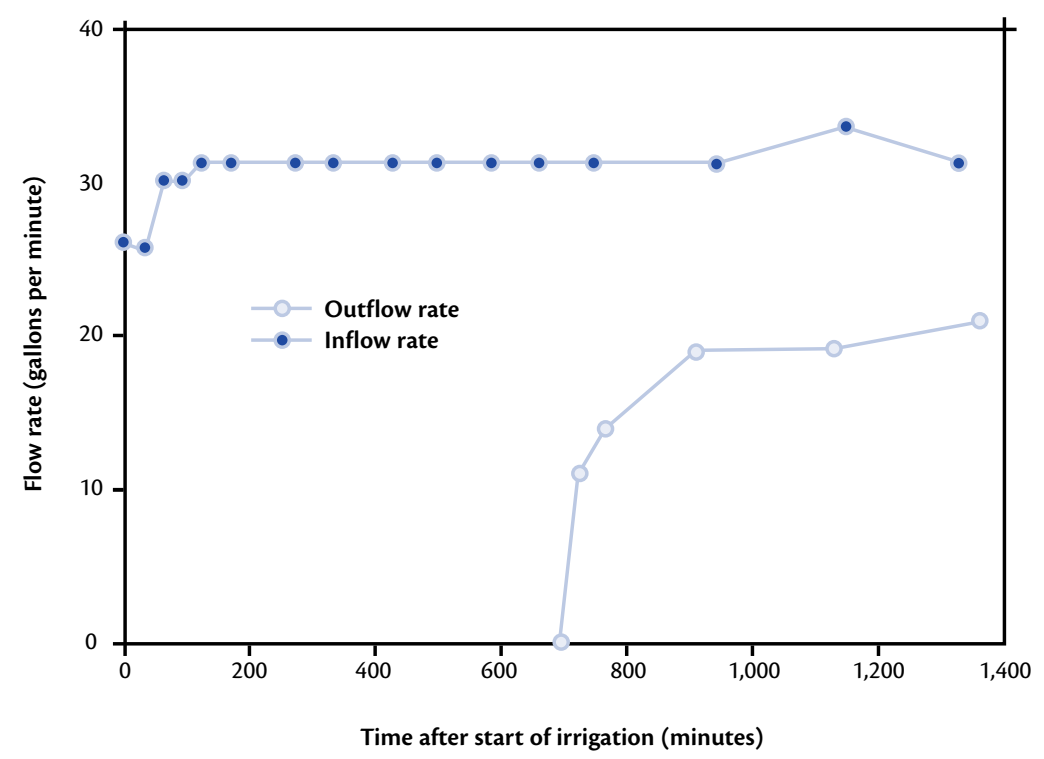

Figure 1. Furrow inflow and outflow rates during irrigation (gallons per minute). Surface runoff outflow is initially very small when water first reaches the end of the field but increases with time.

- At cutoff, irrigation water application ceases. Shortly after cutoff, surface runoff comes to an end because the small amount of ponded water in the furrow infiltrates.

- The cutoff for furrow irrigation should occur after sufficient water has infiltrated the soil along the lower part of the field to meet crop needs. To achieve this, inflow into the furrow is continued after the water reaches the end of the field, to provide sufficient ponding time to infiltrate the desired amount of water at the end of the field. This continued inflow results in surface runoff. Surface runoff cannot be avoided under furrow irrigation without risking injury to the crop from lack of water.

- Infiltration times vary along the field length, resulting in more water infiltrating some parts of the field than others. Normally, under furrow irrigation, infiltration will be greatest along the upper end of the field and lowest at the lower end of the field.

\section{What causes water-induced erosion?}

Soil erosion during irrigation can cause several water quality problems for receiving waters, including increased turbidity and the offsite transport of sediment-associated pollutants such as pesticides and phosphorus. The degree to which soils erode during irrigation depends on a soil's inherent properties, its condition, and the velocity of the water. The soil's inherent properties are determined by the aggregate stability, which is primarily defined by soil texture, organic matter content, compaction, and soil moisture content. Soil conditions include the amount, size, and density of loose particles on the soil surface.

During irrigation, as water flows over the soil surface down a furrow it exerts lift and drag forces that can detach and move soil particles. Some of the drag forces can be absorbed by crop residue in the furrow. Suspended sediments in the water will be transported by the flow for a distance that depends on the soil particle or aggregate size and density, and the transport capacity of the flowing water. The transport process consists of two components: the suspended load, and a rolling, sliding, and bouncing process known as bedload transport. Larger particles (sand) may be mainly transported by bedload transport, while small particles (clay and silt) may be transported as suspended load. These small particles are kept in suspension by turbulence in the flowing water.

\section{Reducing Surface Runoff during Irrigation}

Improving the efficiency of furrow irrigation involves reducing deep percolation below the root zone or reducing surface runoff, or both. However, caution must be used in implementing standard recommendations for improving furrow irrigation because measures that reduce deep percolation can have the undesirable effect of 
increasing surface runoff. This section discusses standard measures commonly recommended for improving furrow irrigation and their effect on surface runoff.

\section{Increasing Flow Rate}

Increasing the flow rate is commonly recommended to reduce deep percolation, but it can also increase surface runoff. The idea is that increasing the flow rate will reduce the amount of time the water takes to reach the end of the field, which will decrease differences in infiltration along the field. Yet field evaluations show that increasing the flow rate makes only a minor improvement in the performance of furrow irrigation because the higher flow rate also increases the depth of water ponded in the furrow, which in turn increases the infiltration of water into the soil. This deeper water in the furrow is likely to contribute to greater runoff.

\section{Reducing Furrow Length}

Reducing the length of furrows is highly effective in reducing deep percolation, but it can substantially increase surface runoff. Shorter furrows decrease the differences in infiltration along the furrow and reduces irrigation time. Studies have shown that shortening furrows by one-half can reduce percolation by at least 50 percent. However, irrigating a given area with shorter furrows may increase surface runoff due to the smaller time required for water to reach the end of the field.

\section{Selecting an Appropriate Cutoff Time}

The cutoff time is the time at which an irrigation set ends and no more water flows down the furrow. Shortening the amount of time a field is irrigated can reduce the amount of surface runoff from furrow-irrigated crops. The amount of time needed to irrigate a given field depends on the time needed to infiltrate sufficient water along the lower part of the field; this may need to be determined on a trial-and-error basis. For example, in cracked clay soils, water flows rapidly into the cracks, resulting in a very high initial infiltration rate. After the cracks close, infiltration rates become very small. The cutoff time should occur about 2 to 3 hours after water reaches the end of the field in these cracked clay soils, thus potentially reducing runoff.

\section{Blocking Furrows}

Some irrigators make small dams in furrows using dirt, plastic furrow dams, or plant material to help slow the water. This practice can conserve water, increase infiltration, and help water flow more evenly across fields so that surface flow in all furrows occurs more uniformly. Monitoring irrigation flows down each furrow while growing crops is, however, labor-intensive. This practice can eliminate surface runoff.

\section{Converting to Sprinkler or Drip Irrigation}

Properly designed and maintained sprinkler and drip irrigation systems for field crops can enhance irrigation efficiency and help eliminate surface runoff. However, this conversion increases capital costs over that of furrow irrigation, so it is generally practiced only on high-value crops such as tomatoes and other vegetable crops. Growers making this conversion must weigh the costs versus benefits of installing these irrigation systems, since the impact of the conversion on yield may be unpredictable.

\section{Recovering Surface Runoff}

Surface runoff can be eliminated by either recirculation or storage and reuse systems. Recirculation systems collect surface runoff in a small reservoir or tailwater pond at the lower end of the field and then recirculate the water onto the same field. The recirculated water should be used on a part of the field that has yet to be irrigated, 
to reduce the volume of water in the tailwater pond. Simply recirculating the runoff to the same irrigation set that generated the runoff only ponds more water on the soil surface, resulting in runoff. Storage and reuse systems collect all of the surface runoff from a field in a tailwater pond and then used to irrigate another field with the water at the appropriate time. This approach requires a farm with multiple fields, a relatively large reservoir, and a distribution system to convey surface runoff to the storage reservoir and to convey the stored water to the desired fields.

\section{Improving the Quality of Surface Runoff}

Practices that can improve the quality of surface runoff from furrow-irrigated fields include sediment traps, vegetated drainage ditches, and adding polyacrylamide (PAM) to source water to help flocculate suspended soil particulates and cause them to settle out of solution. These practices target offsite movement of sediment and sediment-associated pesticides, as well as other pollutants. Vegetated ditches also help reduce offsite movement of pesticides dissolved in solution, primarily through increased soil infiltration. The impact of these practices on receiving waters depends on how they are designed and implemented as discussed in this section.

\section{Sediment Traps}

A sediment trap can best be defined as a basin constructed to collect and store sediment that would otherwise be carried from the field by surface water runoff ( fig. 2). Sediment traps are different from tailwater collection ponds in that they may be smaller and there is no pump and return system to reuse the water for irrigation. Sediment traps have inlets and outlets: surface runoff flows from the outlet into the receiving waters. Sediment traps may be the next step to consider for improving tailwater quality after source control measures such as furrow irrigation system improvements and application of PAM (see below) have been implemented or at least considered.

The concept behind a sediment trap is to use a basin or trap to temporarily retain the irrigation tailwater for a reasonable period of time to reduce the flow velocity and turbulence. This holding period may provide sufficient time for a significant portion of the suspended material to settle out of the water. The trap would also capture larger particles that are not suspended but move along the bottom of the furrow as bedload. The result would be improved quality of the tailwater that exits the trap and flows into receiving waters.

Two variables largely determine the design and effectiveness of sediment traps for reducing pesticides in tailwater runoff and improving water quality. The first is the characteristics of the pesticides involved. For example, fields treated with water-soluble pesticides have a low coefficient of adsorption to soils, so a sediment trap is ineffective. These pesticides are dissolved in the aqueous portion of the runoff and will simply flow through the trap into the receiving waters. The second variable is the makeup of the sediment particulate in the runoff, which is largely influenced by the soil texture and surface soil condition at the time the field is irrigated. Coarse-grained or large-aggregated soil particles settle out of the runoff much more rapidly than do fine-grained silt and clay particles (table 2). For example, medium sand particles would be expected to settle at a rate of 1 vertical foot in 2.3 minutes, silt particles in 2.6 hours, and clay particles in several days. If runoff comes from 
Table 2. Effect of soil particle size in runoff on settling times in sediment traps

\begin{tabular}{|l|c|c|c|c|c|}
\hline $\begin{array}{l}\text { Smallest particle } \\
\text { size trapped }\end{array}$ & $\begin{array}{c}\text { Particle } \\
\text { diameter } \\
\text { (mm) }\end{array}$ & $\begin{array}{c}\text { Settling time* } \\
\text { (sec/inch) }\end{array}$ & $\begin{array}{c}\text { Settling time } \\
\text { (min/ft) }\end{array}$ & $\begin{array}{c}\text { Settling time } \\
\text { (hr/ft) }\end{array}$ & $\begin{array}{c}\text { Settling time } \\
\text { (day/ft) }\end{array}$ \\
\hline medium sand & 0.500 & 11.4 & 2.3 & - & - \\
fine sand & 0.175 & 92.7 & 18.5 & 0.3 & - \\
silt & 0.060 & 788.3 & 157.7 & 2.6 & 0.1 \\
fine silt & 0.006 & 78833 & - & - & 10.9 \\
clay & 0.002 & 709497 & - & - & 98.5 \\
\hline
\end{tabular}

Source: Adapted from Gibbs et al. 1971.

Note: *Settling times were estimated for each minimum particle size description using Stokes' Law and the assumption that soil particle density equals $2.65 \mathrm{~g} / \mathrm{cm}^{3}$.

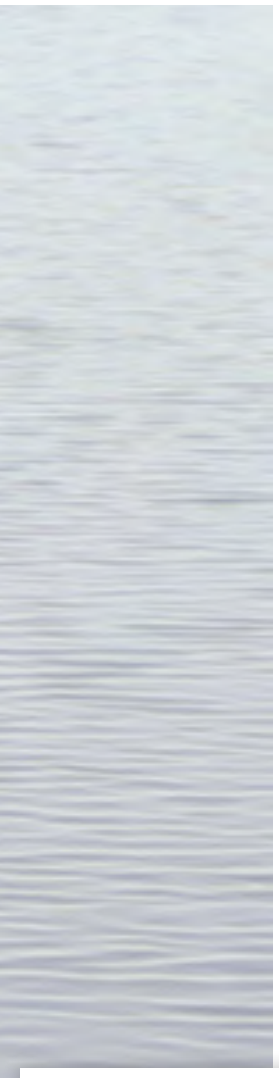

Top view

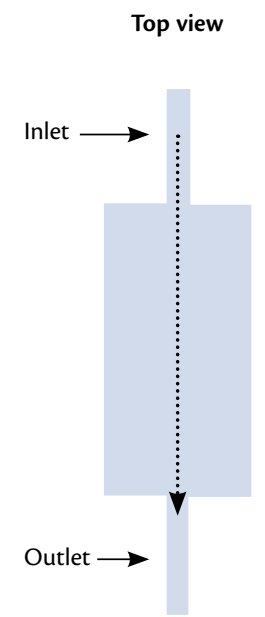

recently cultivated coarse-textured loamy sand and sandy loam soils, the tailwater is likely to contain higher fractions of sand and coarse silt particles and less clay. In this case, substantial amounts of sediment may be captured with a sediment trap.

Tailwater from croplands consisting of finetextured silt and clay soils has a high fraction of suspended silt and clay particulates in the runoff. Under these conditions, sediment traps will not be as effective because of the slow particlesettling rate. Fine-grained particles such as silt, clay, and plant-derived particles not only remain suspended in the water for long periods of time, they also generally have far higher concentrations

Cross-section view

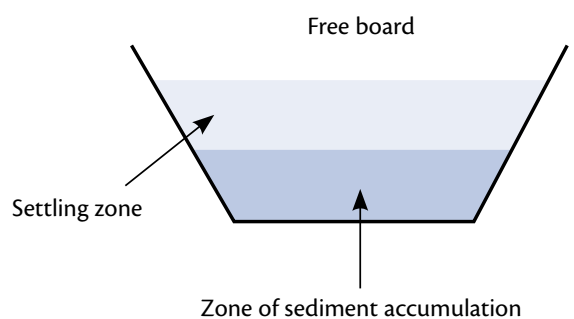

Zone of sediment accumulation of pesticides on them than does coarse-grained sediments. Thus, as coarse-grained material having a low pesticide content settles out of the water. Meanwhile, a phenomenon known as pesticide enrichment occurs in which the remaining suspended material appears to contain higher and higher concentrations of pesticides (i.e., much of the mass of suspended material is lost through settling of coarse particles, but much of the mass of the pesticide remains in the water on fine particles). This phenomenon means that while a sediment trap may capture a great deal of sediment, it may capture little of the pesticide because most of it is transported on the fine material.

Sediment traps should be constructed in rectangular or linear shapes that help spread the water in the trap and provide a relatively long, slow, turbulent-free flow path for suspended sediments to settle out (fig. 2). The features of the land available for constructing sediment trays may dictate shape and design considerations. When earthen sediment traps are constructed, banks should be sloped at 1:1 to minimize bank erosion and prevent sloughing, which might otherwise add suspended sediment to the tailwater. Small sediment traps designed for smaller runoff flows may be constructed of concrete.

Figure 2. General sediment trap design. 
Table 3. Approximate volume of trap storage needed to effectively settle suspended sediments 1 vertical foot given time and selected characteristics of suspended sediment (from table 2 ) and runoff flow rates

\begin{tabular}{|c|c|c|c|c|c|c|c|c|c|c|c|c|}
\hline \multirow{2}{*}{$\begin{array}{l}\text { Smallest } \\
\text { particle } \\
\text { trapped }\end{array}$} & \multirow{2}{*}{$\begin{array}{c}\text { Particle } \\
\text { diameter } \\
(\mathrm{mm})\end{array}$} & \multirow{2}{*}{$\begin{array}{c}\text { Settling } \\
\text { time } \\
\text { (hr/ft) }\end{array}$} & \multicolumn{10}{|c|}{ Runoff flow rates (gpm) } \\
\hline & & & 50 & 100 & 200 & 300 & 400 & 500 & 750 & 1,000 & 1,500 & 2,000 \\
\hline & & & \multicolumn{10}{|c|}{ Storage needed* } \\
\hline $\begin{array}{l}\text { medium } \\
\text { sand }\end{array}$ & 0.500 & 0.04 & $40 \mathrm{ft}^{3}$ & $79 \mathrm{ft}^{3}$ & $159 \mathrm{ft}^{3}$ & $238 \mathrm{ft}^{3}$ & $318 \mathrm{ft}^{3}$ & $397 \mathrm{ft}^{3}$ & $596 \mathrm{ft}^{3}$ & $795 \mathrm{ft}^{3}$ & $1,192 \mathrm{ft}^{3}$ & $1,590 \mathrm{ft}^{3}$ \\
\hline fine sand & 0.175 & 0.3 & $324 \mathrm{ft}^{3}$ & $649 \mathrm{ft}^{3}$ & $1,298 \mathrm{ft}^{3}$ & $1,947 \mathrm{ft}^{3}$ & $2,596 \mathrm{ft}^{3}$ & $3,245 \mathrm{ft}^{3}$ & $4,867 \mathrm{ft}^{3}$ & $6,489 \mathrm{ft}^{3}$ & $9,734 \mathrm{ft}^{3}$ & $0.30 \mathrm{ac}-\mathrm{ft}$ \\
\hline coarse silt & 0.060 & 2.6 & $2,760 \mathrm{ft}^{3}$ & $5,521 \mathrm{ft}^{3}$ & $0.25 \mathrm{ac}-\mathrm{ft}$ & $0.38 \mathrm{ac}-\mathrm{ft}$ & $0.51 \mathrm{ac}-\mathrm{ft}$ & $0.63 \mathrm{ac}-\mathrm{ft}$ & $0.95 \mathrm{ac}-\mathrm{ft}$ & $1.3 \mathrm{ac}-\mathrm{ft}$ & $1.9 \mathrm{ac}-\mathrm{ft}$ & $2.5 \mathrm{ac}-\mathrm{ft}$ \\
\hline fine silt & 0.006 & 263 & $6.3 \mathrm{ac}-\mathrm{ft}$ & $12.7 \mathrm{ac}-\mathrm{ft}$ & $25.3 \mathrm{ac}-\mathrm{ft}$ & $38.0 \mathrm{ac}-\mathrm{ft}$ & $50.7 \mathrm{ac}-\mathrm{ft}$ & $63.4 \mathrm{ac}-\mathrm{ft}$ & $95.1 \mathrm{ac}-\mathrm{ft}$ & $126.7 \mathrm{ac}-\mathrm{ft}$ & $190.1 \mathrm{ac}-\mathrm{ft}$ & $253.5 \mathrm{ac}-\mathrm{ft}$ \\
\hline clay & 0.002 & 2365 & $57.0 \mathrm{ac}-\mathrm{ft}$ & $114.1 \mathrm{ac}-\mathrm{ft}$ & $228.1 \mathrm{ac}-\mathrm{ft}$ & $342.2 \mathrm{ac}-\mathrm{ft}$ & $456.2 \mathrm{ac}-\mathrm{ft}$ & $570.3 \mathrm{ac}-\mathrm{ft}$ & $855.5 \mathrm{ac}-\mathrm{ft}$ & $\begin{array}{c}1,140.6 \\
\text { ac-ft }\end{array}$ & 1,710.9 ac-ft & $2,281.2 \mathrm{ac}-\mathrm{ft}$ \\
\hline
\end{tabular}

Source: Adapted from Marshall and Holmes 1979.

Note: ${ }^{*} \mathrm{ft}^{3}=$ cubic foot; ac-ft $=$ acre-foot. $1 \mathrm{ac}-\mathrm{ft}=43,560 \mathrm{ft}^{3}$. For metric units, see the table at the end of this publication.

Table 3 provides guidelines for designing and constructing sediment traps. The volume of trap storage or resident holding time needed to effectively settle out suspended sediments in runoff is approximated for a range of runoff flow conditions and particulate sizes of the suspended sediments. These approximations are based upon Stokes' Law, where the settling times of suspended sediments can increase 10, 100, or more than 1,000 times as the particle size of the suspended sediments decreases.

The approximations in table 3 suggest that sediment traps be designed 2.5 times larger than that needed for the actual holding time. This 2.5 times adjustment allows for the bottom portion of the trap (about 40 percent of the total trap volume) to accumulate sediments within or over several irrigation seasons, to make trap cleaning and maintenance less frequent. The middle and upper portion of the trap (about 40 percent of the trap volume) function as the active portion of the trap, where tailwater enters and flows through. Sediments settle out to the lower portion, and higher-quality tailwater flows out. The remaining 20 percent of the trap volume provides "free board" and a place to construct inlets and outlets. Free board is the distance between the crown, or top, of the trap and the surface of the water inside the trap, which it protects against overtopping the banks during periods of high flow or from wave action due to wind. The suggested design factor of 2.5 may be adjusted downward, to some extent, to reduce the sediment storage volume and the costs associated with building the traps.

Sediment traps are more feasible for trapping coarser suspended sediments than fine sediments (see table 2). Table 3 shows that approximately 40 cubic feet $\left(\mathrm{ft}^{3}\right)$ of storage volume per 50 gallons per minute (gpm) of runoff flow is needed to trap medium-grain sand and coarse particles. In comparison, for the same runoff flow rate of 50 gallons per minute approximately 324 cubic feet is needed to trap fine sand and coarser particles; 2,760 cubic feet is needed to trap fine silt and coarser suspended particles; and 6.3 and 57 acre-feet (ac-ft) are needed to provide enough holding time to settle fine silt and clay particles, respectively, 1 vertical foot ( 1 acre-foot equals 43,560 cubic feet). Thus, sediment traps may be very useful to trap coarse sediments but are probably not feasible for trapping fine sediments. If the predominant suspended sediments in the runoff are fine silts and clays that pose a risk of transporting adsorbed pesticides, it may make sense to direct the runoff through vegetative filters or use PAM instead of a sediment trap. 


\section{Vegetated Drainage Ditches}

Vegetated ditches are drains planted with vegetation that are designed to capture and filter surface water runoff from crops to protect water quality (fig. 3). The three main processes responsible for the effectiveness of these filter strips in reducing pesticides in surface runoff are sedimentation, infiltration, and adsorption. Sedimentation is the tendency for particulates and sediment-sorbed pesticides to settle out of suspension as the water slows down and flows through a filter strip. Infiltration is the process by which pesticides in solution and on fine particulates penetrate the soil, where they are usually broken down to less-toxic forms than the parent material by microbial activity. Adsorption is the process by which pesticides are taken out of solution as the water flows through a strip by the aboveground vegetation and soil surface, where they may be broken down to nontoxic forms by natural processes such as sunlight and microbial activity.

Vegetated ditches have been documented to significantly reduce the offsite movement of water-soluble pesticides as well a those that attach to sediments (Moore et al. 2008). The degree to which these filter strips function

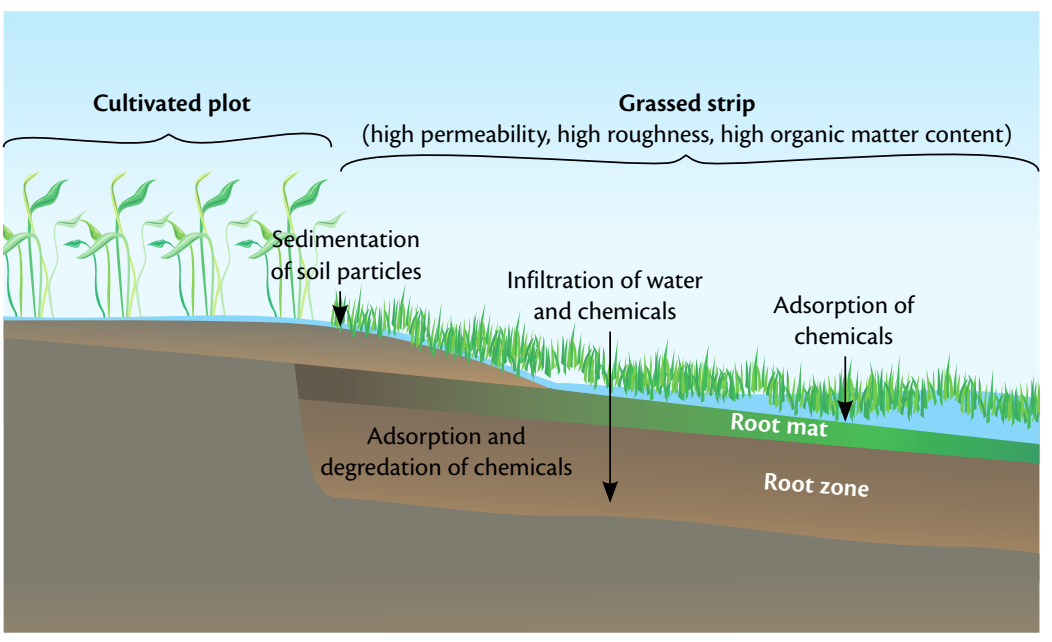

Figure 3. Processes in a vegetated ditch that minimize sediments and pesticides and other pollutants in irrigation runoff.

Source: After Lacas et al. 2005. depends on their size, slope, density, the height of the vegetation selected, and the degree of soil saturation. Their effectiveness is also influenced by the size of the cultivated field and slope, the erosion rate, the volume and velocity of tailwater, and the sediment inflow, including grain size, aggregation, and concentration. Specific pesticide properties such as the degree of water solubility and how tightly the pesticide binds to sediments also affect how well vegetated ditches can protect water quality: for example, sediment-associated pesticides such as pyrethroids are more likely to be trapped via sedimentation than water-soluble ones that may flow through the filter strip.

As a result of the many variables involved in how well filter strips function, it is difficult to predetermine the size needed to effectively filter a given runoff volume from a given field. The best vegetated ditch would be one that captures all of the water (and thus all sediments and pesticides) coming off a field. However, this may not be practical because the size of the filter strip needed to filter a given volume of tailwater may take too much cropland out of production to make it economically viable.

In research trials in the Sacramento Valley, a 5-foot-wide by 160 -foot-long filter strip ( $800 \mathrm{ft}^{2}$ ) planted to fescue and ryegrass reduced sediment and pyrethroid loads in tailwater by 60 percent from crop sites that were 0.7 acres in size (Long et al., in press). Field length at the crop site was 650 feet, and the crop was furrow-irrigated at 
a rate of 15 to 20 gallons per minute per furrow. The runoff entering the filter strip reached a maximum flow of about $55 \mathrm{gpm}$ and diminished to a very low flow (estimated to be less than 5 gallons per minute) that was difficult to measure due to the slow velocity at the end of the filter strip. As a rough approximation and guideline for sizing filter strips, this experience suggests that about 1,450 square feet (0.03 acre) of vegetative filter may be needed per 100 gallons per minute of tailwater to significantly improve the water quality of field runoff.

Prior to establishing vegetated ditches on farms it is important to conduct a whole-farm analysis to assess how and where the water flows, along with volume and velocity, to determine how to best incorporate them on farms. Investing in a vegetated ditch is costly, both in time and money, and must therefore be evaluated carefully against to other water quality protection strategies that may be implemented on farms. One strategy would be to plant existing drainage ditches on farms with perennial grasses; another would be to create new vegetated ditches on farms in areas that would capture and filter surface water before being discharged into drains (see Grismer et al. 2006). The following discussion summarizes the practices involved in installing vegetated ditches on farms.

\section{Site selection and analysis}

Vegetated ditches must be placed at the ends of fields where runoff can be directed. The water would flow through the strips, following the grade of the field, and discharge into a main drain. The area selected should be readily accessible to farm equipment for site preparation and maintenance. The site should not disrupt normal farming operations or be in an area that could be easily overlooked and accidentally disked or sprayed. In addition, the site should be well drained to prevent ponding of water or plant dieback.

\section{Site design}

Vegetated ditches should capture and contain irrigation tailwater in a manner that reduces runoff and increases infiltration. The filter strip should be wide enough to maintain a sheetlike flow at or below the height of the vegetation to provide adequate contact between the flowing water and the grass.

\section{Plant selection}

Vegetated ditches are most effective when planted with perennial grasses such as tall fescue (Festuca arundinacea) (endophyte-free if grazed as a forage) and perennial ryegrass (Lolium perenne). These grasses are hardy and will grow quickly and form a thick thatch to filter and trap sediments and sediment-associated pesticides. Grasses help water infiltrate more rapidly than do broadleaf plants such as clovers (Trifolium spp.). Creeping wildrye (Leymus triticoides) is a California native perennial grass that would also work well in a filter strip, but it is slow to establish.

\section{Site preparation and planting}

To prepare the area selected for a vegetated ditch, disk and shape the land to carry water and prepare a normal seedbed. Grasses should be planted in the fall when establishment is favored by cool weather and subsequent winter rains. After the seedbed is prepared, allow the winter rains to bring up the first flush of winter weeds. These should be either sprayed with Roundup (glyphosate) or disked. The grasses should then be direct-seeded with a grain drill at 15 pounds per acre by late fall. They can also be broadcast at 20 to 25 pounds per acre and incorporated with a chain harrow followed by rolling. Buctril (bromoxynil), MCPA (2-methyl-4-chlorophenoxyacetic acid), or 2,4-D (2,4-dichlorophenoxyacetic acid) can be used to control broadleaf weeds once the grasses have established and have been allowed to grow at least 3 to 4 inches tall to avoid injury to newly emerged seedlings. Be sure to contact the local 
agricultural commissioner for restrictions on the use of herbicides. For example, the phenoxys MCPA and 2,4-D cannot be used after March 1 in many counties. Once the grasses are established, they will compete well with weeds, requiring only occasional use of herbicides, hand weeding, or mowing.

\section{Maintenance}

Since most of the sedimentation or particle retention occurs at the beginning of the filter strip, this area should be closely monitored, and excess sediment should be removed to keep water from diverting to new and easier drainage routes or channels. This may involve reestablishing the grasses by overseeding the area to ensure that a sheetlike flow is maintained as the water comes off farm fields. Gophers and ground squirrels should be controlled and repairs made where channelization of water occurs. Irrigation runoff should supply the water needs of the vegetation in the ditches.

Grasses may need to be mowed occasionally to prevent thatch from building up and to

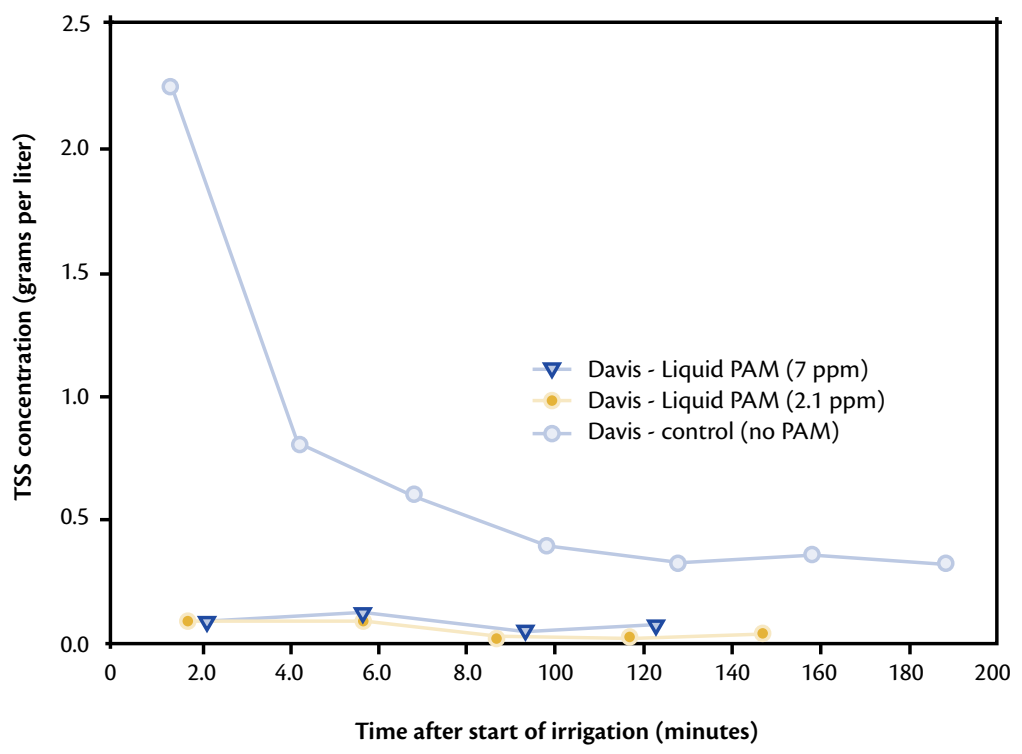

Figure 4. Suspended sediment concentrations in grams per liter of water in the Sacramento Valley for untreated versus PAM-treated furrows at PAM concentrations of 2.1 and $7 \mathrm{ppm}$ in the irrigation water. PAM was not applied to the control treatment. deter weeds. If the vegetated drain is grazed, the animals should be watched to prevent overgrazing and stand loss, especially on wet soils. Plant tissue testing may also be needed to ensure that nutrients concentrated in the filter strips have not built up to unhealthy levels for the animals.

\section{Polyacrylamide (PAM)}

One method promoted for improving surface water quality runoff from furrow-irrigated agricultural fields is to apply a polyacrylamide (PAM, a material synthesized from natural gas) to the irrigation water. PAM stabilizes the soil to minimize erosion and promotes the settling of suspended particles. PAM comes in tablet, granular, and liquid (oil- or water-based) formulations. By itself, PAM is not toxic to aquatic life; however, the carriers in oil-based PAM can be toxic to aquatic life at recommended field application rates. For this reason, water-based formulations are recommended (Weston et al. 2009).

In research trials conducted by the authors at the University of California, Davis, liquid PAM in a loam soil significantly reduced suspended sediment concentrations compared with a control of untreated water in surface runoff at PAM concentrations of $2.1 \mathrm{ppm}$ and $7 \mathrm{ppm}$ in the source irrigation water ( fig. 4). Similar behavior occurred in a clay loam soil at a second field site at California State University, Chico, with a PAM concentration of $1.1 \mathrm{ppm}$. Terminating the liquid PAM injection once the water reaches the end of the furrows can be as effective as continuous PAM dosing, but this effect may depend on soil texture. 
Studies on tablet and granular PAM at Davis and Chico showed a similar response to the liquid PAM, with significant reductions in suspended sediment concentrations compared to untreated water (fig. 5). However, proper placement of dry PAM in the furrows was critical for efficacy. In studies in Idaho conducted by the USDA, dry PAM placed at the head of the furrow was effective. However, at Davis and Chico similar placement of dry PAM at the furrow head resulted in the material being quickly covered by eroded sediment during irrigation, and the PAM lost its efficacy. In contrast, dry PAM material placed 100 to 300 feet down the field was not covered by sediment and was effective in reducing the sediment concentrations.

Proper placement of dry PAM is particularly important for gated pipe systems, where water discharged from gates may cause considerable erosion at the head of the furrow. One way to lesson this erosion is to place irrigation socks over the gates. PAM applications had no effect on irrigation water infiltration rates for the soil types

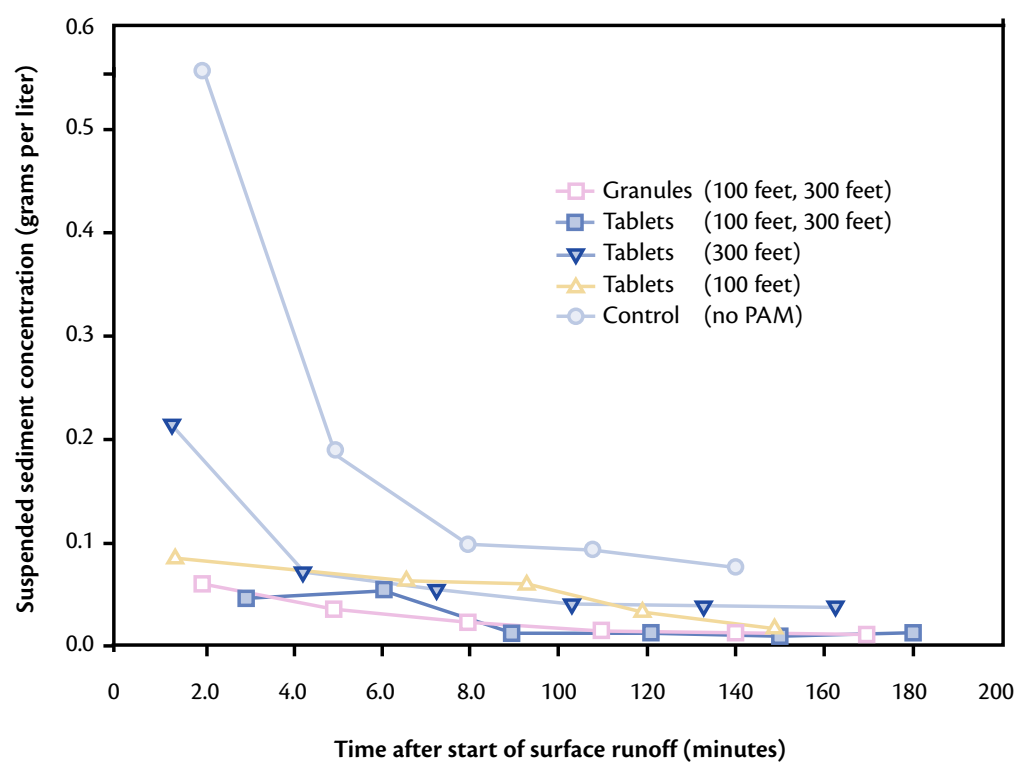

Figure 5. Suspended sediment concentrations in grams per liter of water for untreated furrows and for furrows with PAM tablets or granules placed in the furrow at a distance of either 100 feet or 300 feet, or both, from the furrow head. evaluated in the Sacramento Valley, whereas infiltration increased with the addition of PAM in an Idaho study (Sojka et al. 2007).

\section{PAM application recommendations}

- Inject liquid PAM into the irrigation source water. The PAM injection rate $\left(\mathrm{Q}_{\mathrm{PAM}}\right)$ depends on the target PAM concentration $\left(\mathrm{C}_{\mathrm{i}}\right)$, the irrigation water flow rate $\left(\mathrm{Q}_{\mathrm{i}}\right)$, and the PAM concentration in the liquid material $\left(\mathrm{C}_{\mathrm{PAM}}\right)$ and can be calculated by $\mathrm{Q}_{\mathrm{PAM}}=\left(\mathrm{C}_{\mathrm{i}}\right.$ $\left.\times \mathrm{Q}_{\mathrm{i}}\right) \div \mathrm{C}_{\text {PAM }}$. So, for example, if the target PAM concentration is $5 \mathrm{ppm}$, the irrigation flow rate is $2,000 \mathrm{gal} / \mathrm{min}$, and the injected solution is $25 \%$ PAM (250,000 ppm in 1 gallon of material), then the injection rate would be 0.04 gallons per minute. Although PAM concentrations of 1 to 2 ppm were effective in the Chico and Davis trials, a PAM concentration of about $5 \mathrm{ppm}$ is recommended to account for different soil types and degrees of soil erosion.

- Dissolve PAM granules in the water in the irrigation ditch or pipeline. The application rate will depend on the flow rate of the irrigation water and can be determined from figure 6. For example, a target PAM concentration of $5 \mathrm{ppm}$ and an irrigation water flow rate of 2,000 gallons per minute will require a granule application rate of 1.3 ounces per minute.

- Place dry PAM material (tablets or granules) about 100 feet from the head of the furrow. PAM granules should be applied at rate of 1 ounce per furrow with the material spread over a 3-foot section. If using tablets, two tablets per furrow are recommended at 100 and 300 feet. However, it would be a good idea to experiment with one and then two tablets per furrow to see which works best on a particular field, since efficacy of the tablets may vary by soil type and the degree of erosion. 


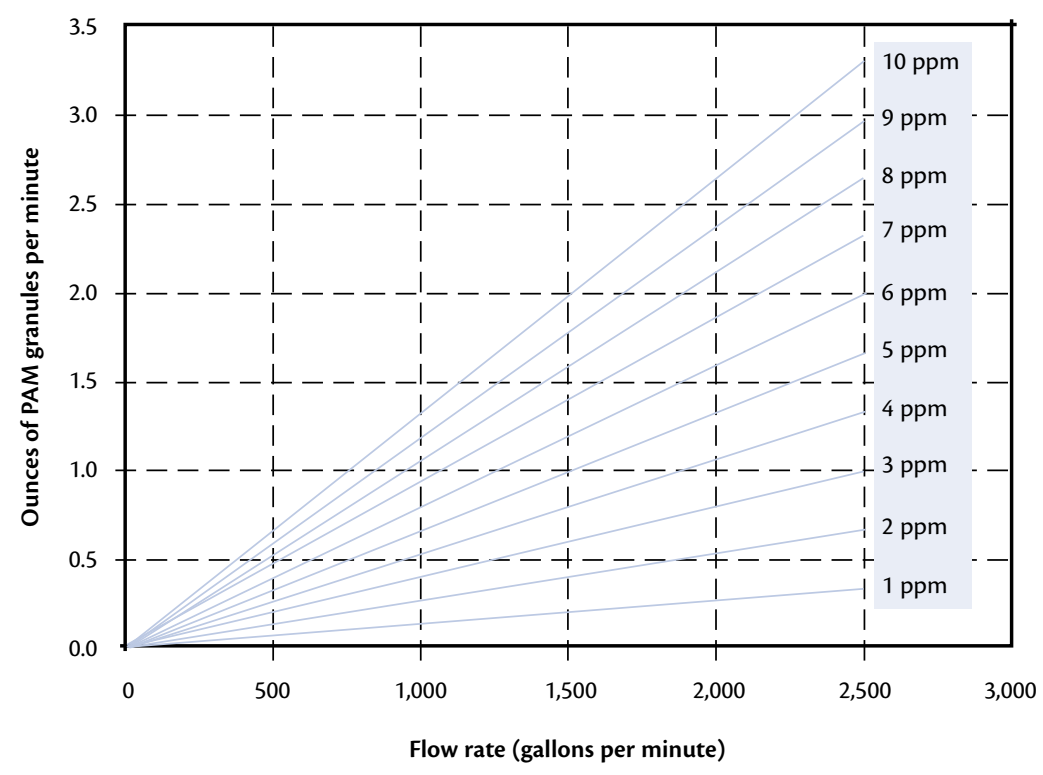

Figure 6. Application rate of PAM granules (oz) into irrigation water for different target PAM concentrations and different irrigation water flow rates.

Source: Lentz and Sojka 2009.

- PAM-treated soils should not be disturbed.

Only a thin layer of surface soil will be stabilized after applying this material; cultivation or other disturbance will require reapplication of PAM. Reapplication will also be necessary after 2 to 3 irrigations because the effectiveness of the PAM diminishes.

- PAM should be injected into the irrigation water at least until the water reaches the end of the field. For some soil types, stopping the PAM treatment after the water reaches the end of the field (while continuing to irrigate) will not increase the sediment concentration of the runoff. However, for other soil types, stopping the PAM injection after the water reaches the end of the field may increase the suspended sediment concentration to that of untreated irrigation water runoff.

The cost of applying PAM depends on how it is applied to the field. The cost of dry PAM formulations placed in the furrows depends on the material cost, the furrow spacing, and the number of tablets per furrow. PAM application rates are based on recommended rates for each type of PAM material (granules, tablets, or liquid). The smaller the row spacing ( for example, 30-inch beds versus 60 -inch beds), the larger the cost will be for a given acreage. Whether to apply dry PAM directly into the irrigation water or use liquid PAM depends on the target PAM concentration in the irrigation water, the material cost, the flow rate of water into the field, and the injection time.

Table 4 shows cost comparisons using different rates and formulations of PAM on an 80-acre furrow-irrigated row crop planted on 5 -foot beds using data provided by a grower. Costs per acre are based on the total field acreage (80 acres). In this field example, the time for the water to reach the end of 1,200 -foot furrows is 12 hours; there are four irrigation sets (20 acres per set); a flow rate of 1,320 gallons per minute; and a furrow flow rate of 11 gallons per minute. The lowest cost occurred for granules placed in the furrow, while the highest cost was for using

Table 4. Sample costs for selected PAM formulations for an 80-acre furrow-irrigated row crop planted on 5-foot beds, using recommended PAM application rates and information provided by a grower

\begin{tabular}{|l|c|c|c|}
\hline Application method & Unit cost of material & Cost per acre & Comments \\
\hline granules placed in furrow & $\$ 2.79 / \mathrm{lb}$ & $\$ 1.05$ & 1 oz of granules per furrow \\
\hline tablets placed in furrow & $\$ 4.82 / \mathrm{lb}$ & $\$ 6.36$ & Two tablets per furrow $^{*}$ \\
\hline granules injected into irrigation water & $\$ 2.79 / \mathrm{lb}$ & $\$ 5.46$ & target concentration $=5 \mathrm{ppm}^{*}$ injection time $=12 \mathrm{hr}^{\dagger}$ \\
\hline liquid PAM injected into irrigation water & $\$ 34 / \mathrm{gal}$ & $\$ 32.31$ & target concentration $=5 \mathrm{ppm}$; injection time $=12 \mathrm{hr}^{\dagger}$ \\
\hline liquid PAM injected into irrigation water & $\$ 34 / \mathrm{gal}$ & $\$ 12.93$ & target concentration $=2 \mathrm{ppm}$; injection time $=12 \mathrm{hr}{ }^{\dagger}$ \\
\hline
\end{tabular}

Note: ${ }^{*}$ The efficacy of the tablets may vary by soil type, length of furrow, and the degree of soil erosion.

tTime needed for water advance to end of furrows. 
liquid PAM. The high cost of liquid PAM reflected the cost of the material and the long injection time. Terminating the injection before complete advance to the end of the furrow would reduce the cost per acre but may increase sediment levels.

While the cost per acre of applying liquid PAM in irrigation water is higher than the cost of dry PAM formulations, especially at a concentration of 5 ppm (our recommended application rate), our studies at Chico and Davis showed PAM concentrations of 1 to $2 \mathrm{ppm}$ in the irrigation water to be effective in reducing the sediment load on loam and clay loam soils. As a result, growers should experiment with liquid PAM application rates to determine what works best on their farms, since the efficacy depends on sediment loads as affected by factors such as soil type and irrigation flow rates. The differences in field responses to PAM may be why the NRCS recommends a higher concentration of $10 \mathrm{ppm}$ in irrigation water to reduce sediment loads in surface irrigation runoff; this rate should cover most sediment loads, but it would not be economical.

\section{Additional Resources}

Other methods for reducing soil erosion and protecting water quality than those discussed in this publication include the use of irrigation socks for gated pipe to help distribute water more evenly into the furrows, using drop pipes, lining ditches and inlets, and proper shaping of tailwater ditches.

Contact the Natural Resource Conservation Service (NRCS) for information on cost-share programs available for implementing sediment reduction practices on farms.

\section{ENGLISH-METRIC CONVERSIONS}

\begin{tabular}{|c|c|c|c|}
\hline English & $\begin{array}{l}\text { Conversion factor for } \\
\text { English to Metric }\end{array}$ & $\begin{array}{l}\text { Conversion factor for } \\
\text { Metric to English }\end{array}$ & Metric \\
\hline \multicolumn{4}{|c|}{ Length } \\
\hline inch (in) & 2.54 & 0.394 & centimeter $(\mathrm{cm})$ \\
\hline inch (in) & 25.4 & 0.0394 & millimeter (mm) \\
\hline foot $(\mathrm{ft})$ & 0.3048 & 3.28 & meter $(\mathrm{m})$ \\
\hline \multicolumn{4}{|c|}{ Area } \\
\hline acre (ac) & 0.4047 & 2.47 & hectare (ha) \\
\hline square foot $\left(\mathrm{ft}^{2}\right)$ & 0.0929 & 10.764 & square meter $\left(m^{2}\right)$ \\
\hline \multicolumn{4}{|c|}{ Volume } \\
\hline ounce (oz) & 29.57 & 0.338 & cubic centimeter $\left(\mathrm{cm}^{3}\right)$ \\
\hline gallon (gal) & 3.785 & 0.26 & liter (I) \\
\hline acre-inch (ac-in) & 102.8 & 0.0097 & cubic meter $\left(\mathrm{m}^{3}\right)$ \\
\hline acre-foot (ac-ft) & 1,233 & 0.000811 & cubic meter $\left(\mathrm{m}^{3}\right)$ \\
\hline cubic foot $\left(\mathrm{ft}^{3}\right)$ & 28.317 & 0.353 & liter (I) \\
\hline cubic yard $\left(y d^{3}\right)$ & 0.765 & 1.307 & cubic meter $\left(\mathrm{m}^{3}\right)$ \\
\hline gallon per acre (gal/ac) & 9.36 & 0.106 & liter per hectare (I/ha) \\
\hline \multicolumn{4}{|c|}{ Mass } \\
\hline ounce (oz) & 28.35 & 0.035 & $\operatorname{gram}(\mathrm{g})$ \\
\hline pound (Ib) & 0.454 & 2.205 & kilogram (kg) \\
\hline pound per acre (lb/ac) & 1.12 & 0.89 & kilogram per hectare $(\mathrm{kg} / \mathrm{ha})$ \\
\hline
\end{tabular}




\section{References}

Gibbs, R. J., M. D. Matthews, and D. A. Link. 1971. The relationship between sphere size and settling velocity. Journal of Sedimentary Petrology 41:7-18.

Grismer, M. E., A. T. O'Green, and D. Lewis. 2006. Vegetative filter strips for nonpoint source pollution control in agriculture. Oakland: University of California Agriculture and Natural Resources Publication 8195. UC ANR Web site, http://anrcatalog.ucdavis.edu/SoilWaterIrrigation/8195.aspx.

Lacas, J. G., M. Voltz, V. Gouy, N. Carluer, and J. J. Gril. 2005. Using grassed strips to limit pesticide transfer to surface water: A review. Agronomy for Sustainable Development 25:253-66.

Lentz, R. D., and R. E. Sojka. 2009. Determining dry PAM application rates for head ditch or pipe flow. Kimberly, ID: NWISRL, USDA Agricultural Research Service. ARS Web site, http://www.ars.usda.gov/Services/docs. htm?docid $=18848$.

Long, R. F., J. Gan, and M. Nett. 2005. Pesticide choice: Best management practice (BMP) for protecting surface water quality in agriculture. Oakland: University of California Agriculture and Natural Resources Publication 8161. ANR CS Web site, http://anrcatalog.ucdavis.edu/PesticideUseSafety/8161.aspx.

Long, R. F., B. R. Hanson, A. E. Fulton, and D. Weston. In press. Mitigating offsite movement of pyrethroid insecticides in furrow-irrigated fields in the Central Valley. California Agriculture.

Marshall, T. J., and J. W. Holmes. 1979. Soil physics. Cambridge, UK: Cambridge University Press.

Moore, M. T., D. L. Denton, C. M. Cooper, J. Wrysinski, J. L. Miller, K. Reece, D. Crane, and P. Robins. 2008. Mitigation assessment of vegetated drainage ditches for collecting irrigation runoff in California. Journal of Environmental Quality 37:486-93.

NRCS (Natural Resource Conservation Service). NRCS California Web site, http://www.ca.nrcs.usda.gov/.

Sojka, R. E., D. L. Bjorneberg, J. A. Entry, R. D. Lentz, and W. J. Orts. 2007. Polyacrylamide in agriculture and environmental land management. Advances in Agronomy 92:75-162.

SWRCB (California State Water Resources Control Board). SWRCB Web site, http://www.swrcb.ca.gov/.

UC IPM (University of California Integrated Pest Management). UC IPM pest management guidelines. UC IPM Web site, http://ipm.ucdavis.edu.

Weston, D. P., J. You, and M. J. Lydy. 2004. Distribution and toxicity of sediment-associated pesticides in agriculture-dominated water bodies of California’s Central Valley. Environmental Science and Technology 38:2752-2759.

Weston, D. P., R. D. Lentz, M. D. Cahn, A. K. Rothert, and M. J. Lydy. 2009. Toxicity of various anionic polyacrylamide formulations when used as erosion control agents in agriculture. Journal of Environmental Quality 38:238-247. 


\section{For Further Information}

To order or obtain ANR publications and other products, visit the ANR Communication Services online catalog at http://anrcatalog.ucdavis.edu or phone 1-800-994-8849. You can also place orders by mail or FAX, or request a printed catalog of our products from

University of California

Agriculture and Natural Resources

Communication Services

6701 San Pablo Avenue, 2nd Floor

Oakland, California 94608-1239

Telephone 1-800-994-8849

510-642-2431

FAX 510-643-5470

E-mail: danrcs@ucdavis.edu

(C)2010 The Regents of the University of California

Agriculture and Natural Resources

All rights reserved.

No part of this publication may be reproduced, stored in a retrieval system, or transmitted, in any form or by any means, electronic, mechanical, photocopying, recording, or otherwise, without the written permission of the publisher and the authors.

Publication 8403

ISBN-13: 978-1-60107-682-3

The University of California prohibits discrimination or harassment of any person on the basis of race, color, national origin, religion, sex, gender identity, pregnancy (including childbirth, and medical conditions related to pregnancy or childbirth), physical or mental disability, medical condition (cancer-related or genetic characteristics), ancestry, marital status, age, sexual orientation, citizenship, or service in the uniformed services (as defined by the Uniformed Services Employment and Reemployment Rights Act of 1994: service in the uniformed services includes membership, application for membership, performance of service, application for service, or obligation for service in the uniformed services) in any of its programs or activities.
University policy also prohibits reprisal or retaliation against any person in any of its programs or activities for making a complaint of discrimination or sexual harassment or for using or participating in the investigation or resolution process of any such complaint.

University policy is intended to be consistent with the provisions of applicable State and Federal laws.

Inquiries regarding the University's nondiscrimination policies may be directed to the Affirmative Action/Equal Opportunity Director, University of California, Agriculture and Natural Resources, 1111 Franklin Street, $6^{\text {th }}$ Floor, Oakland, CA 94607, (510) 987-0096. For information about ordering this publication, telephone 1-800-994-8849. For assistance in downloading this publication, telephone 530-754-3927.

To simplify information, trade names of products have been used. No endorsement of named or illustrated products is intended, nor is criticism implied of similar products that are not mentioned or illustrated.

An electronic copy of this publication can be found at the ANR Communication Services catalog Web site, http://anrcatalog. ucdavis.edu.

\section{UCE}

REVIEWEO This publication has been anonymously peer reviewed for technical accuracy by University of California scientists and other qualified professionals. This review process was managed by the ANR Associate Editor for Land, Air, and Water Sciences.

web-3/10-SB/RW 